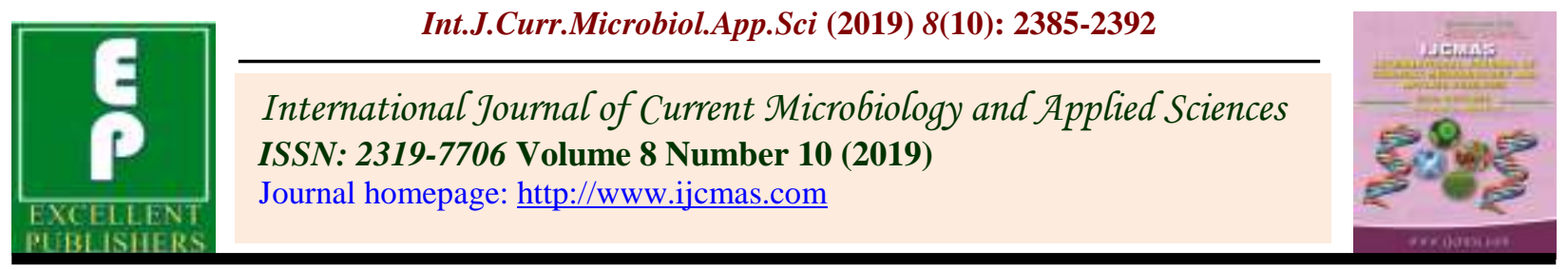

Original Research Article

https://doi.org/10.20546/ijcmas.2019.810.276

\title{
Influence of Organic Manures and Bio-fertilizers on Growth and Yield of Indian Basil (Ocimum sanctum L.) cvs Cim-Ayu and Cim-Angana
}

\author{
Rajit Ram, V.M. Prasad, Vijay Bahadur, Joy Dowsan, \\ Narendra Swaroop and Anil Kumar* \\ Department of Horticulture, SHUATS, Prayagraj, U.P., India \\ *Corresponding author
}

\begin{tabular}{|l|}
\hline Ke y w o r d s \\
Indian basil, \\
Growth, Organic \\
manure and bio- \\
fertilizers
\end{tabular}

The experiment was conducted at Horticulture Research Farm in Department of Horticulture, Sam Higginbottom University of Agriculture Technology and Sciences, Prayagraj, during 2017-18. The experiment was laid out in factorial R.B.D. with 12 treatments with the following combination viz. $\mathrm{T}_{0}=$ Control, $\mathrm{T}_{1}=\mathrm{FYM} @ 20 \mathrm{t} / \mathrm{ha}, \mathrm{T}_{2}=\mathrm{P} . \mathrm{S} . \mathrm{B}$ @ 20t/ha, T $3=$ Vermicompost @6.0 t/ha, T $4=$ Neem Cake @ 3.0t/ha, T $5=$ Azotobacter @ $6.0 \mathrm{~kg} / \mathrm{ha}+$ Mycorrhiza @6.0 kg/ha, T 6 FYM @ 10t/ha+ Vermicompost @ 3.0 t/ha, $\mathrm{T}_{7}=$ Vermicompost @ 3.0 t/ha+ P.S.B @ 10t/ha, T $=$ FYM @ 10t/ha+ Neem Cake @ 1.5t/ha, $\mathrm{T}_{9}=$ P.S.B @ 10t/ha + Neem Cake @ 1.5t/h, T $10=\mathrm{FYM} @ 10 \mathrm{t} / \mathrm{ha}+\mathrm{P} . \mathrm{S} . \mathrm{B} @$ 10t/ha + Neem Cake @ 1.5t/h +Azotobacter, @6.0 kg/ha and T ${ }_{11}=$ FYM @ 10t/ha +P.S.B @ 10t/ha + Neem Cake@1.5t/h +Mycorrhiza@6.0 kg/ha with three replications. The cultivar of Indian basil Cim-Ayu and Cim-Angana attained highest plant height per plant $(1.17 \mathrm{~m}$ and $1.73 \mathrm{~m})$ with $\mathrm{T}_{9}$ followed by with $\mathrm{T}_{10}$, diameter of main stem $(1.16 \mathrm{~m}$ and 1.71 m) with $\mathrm{T}_{10}$ followed by $(9.49 \mathrm{~cm}$ and $9.31 \mathrm{~cm})$ with $\mathrm{T}_{9}$, total number of leaves per plant (1608.90 and 1547.90) with $\mathrm{T}_{10}$ followed by (1524.80 and 1503.00) with $\mathrm{T}_{11}$, total number of branch per plant (17.33 and 15.63) with $\mathrm{T}_{10}$ followed by (17.05 and 16.89) with $\mathrm{T}_{11}$ and highest plant spread $(87.88 \mathrm{~cm}$ and $88.74 \mathrm{~cm})$ with $\mathrm{T}_{10}$ followed by $(80.95 \mathrm{~cm}$ and 81.44 $\mathrm{cm})$ with $\mathrm{T}_{11}$.

\section{Introduction}

Basil was derived from Greek word "Basilica" which means royal plants. Among the Ocimum genus is variously known as Sweet basil, French basil or Common basil. The genus Ocimum belongs to the family Laminaceae (Labiatae) which includes about 3500 species among 210 genera and numerous varieties (Blank et al., 2004). It is native to Indian subcontinent, China, South-east Asia and New Guinea (Kew garden). It was originally domesticated in India. Basil is cultivated over an area of 25,000 ha and it accounts for annual production of about 250300 tonnes of oil, has been cultivated. Ocimum sanctum has widest distribution which covers the entire Indian sub-continent, ascending up to $1800 \mathrm{MSL}$ in the Himalayas and in Andaman and Nicobar Islands. This plant occupies a wide range of habitats. It is an annual herb, cultivated extensively in 
Indonesia, Thailand, Vietnam, USA, Cambodia, Laos, the cuisine of Taiwan, France, Egypt, Hungary, Greece, morocco, Israel and many other regions of the world.

Basil is an erect herbaceous, much branched soft hairy plant with $50-60 \mathrm{~cm}$ plant height and has pink and white colour of flowers. Its ecological demands of temperature range between $7-27^{\circ} \mathrm{C}$, soil $\mathrm{pH} 4.3-8.2$ and annual rainfall $0.6-4.2 \mathrm{~mm}$, different environment condition and planting density causes different growth and yield. The useful parts of basil plant are leaf and seed. The most essential component of basil is essential oil. Essential oil ratio varies between $0.1-4.55$ based on climate conditions. Basil has three forms generally recognized as Rama tulsi with green stems and leave, Krishna tulsi with green stems and some time leaves are purple in colour and Vana tulsi which is unmodified from its wild form.

Basil has been utilized for its stomachs, expectorant, diuretic, carminative and stimulants property in folk medicine. It is also known to be used as an insecticide flea and moth repellent and against snake and insect bite. Recently the use of fresh and dry leaves of plant has been very common in food and spice industry. Traditionally, Leaves and flower of basil has been used as medicinal plants for various ailments, such as headaches, cough, diarrhea, constipation, warts, warms and kidney malfunction, as well as for carminative, antispasmodic and anti-malarial febrifuge properties. Its essential oil are synthesized and stored in glandular hairs and are used as flavorings in food and beverages, as fragrances as toilet product, such as mouth washes and dental creams, as fungicide, or insecticide in pharmaceutical\& industrial products (Mondello et al., 2002).

The essential oils from Ocimum genus find diverse uses in perfumery and cosmetic industries as well as indigenous systems of medicines. The essential oils of basil are extracted via steam distillation from the leaves. Extracted essential oil has also been shown to contain biologically active constituents that are insecticidal, nematicidal and fungicidal. The oil is essential microbial activity. The plant contains mainly phenols, aldehydes, tannins, saponin and fats. Essential oil constitutes Eugenol (71\%), Eugenol methyl ether (20\%), Methyl Chavicol (3\%), Camphor and Mehylcinnamates and minor portions of Nerol, Caryophyllene, Selinene, $\alpha$-pinene, $\beta-$ pinene, Camphor, Cineole and linalool etc. Apart from biologically active compounds, such as, volatile oils terpenese, flavonoids or glycoside are also valuable source of micro and macro elements.

The plant of basil was studied by many researchers to determine yield component, essential oil ratio and composition of essential oil under different ecological conditions, but only a few researches were focused on organic manure and bio fertilizers. Hence, with this background the main aim of present study was focused on evaluation of anti-microbial activity of Ocimum sanctum leaf extract in normal top water and local river water.

Organic Manures plant and animal wastes are used as source of plant nutrients that release nutrients after their decomposition. The art of collecting and using wastes from animal, human and vegetable sources for improving the crop production and productivity is as old as agriculture. The material of organics Manures are derived from animal, human and plant residues which contain plant nutrients in complex organic forms. Naturally occurring or synthetic chemicals containing plant nutrients are called fertilizers. Manures with low nutrient, content per unit quantity have longer residual effect besides improving soil physical properties as compared to fertilizers with high nutrient content. 
Farmyard manures, its refer to the decomposed mixture of dung and urine of farm animals along with litter and left over material from roughages or other green fed to the farm animals. It contains, on an average well decomposed farmyard manure contains 0.5 percent $\mathrm{N}, 0.2$ percent $\mathrm{P}_{2} \mathrm{O}_{5}$ and 0.5 percent $\mathrm{K}_{2} \mathrm{O}$. Usually, dung and urine of animals along with their litter and waste feed are collected and placed in bench daily and when riled in, it is covered with soil, Farm yard manure seems to act directly for increasing the crop yields either by acceleration of respiratory process with increasing cell permeability and hormonal growth action or by combination of all these processes. It supplies nitrogen, phosphorus, potassium and micronutrients like Fe, S, Mo and $\mathrm{Zn}$ etc. in available forms to the plants through biological decomposition and improves physico-chemical properties of soil such as aggregation, aeration, permeability, water holding capacity, slow release of nutrients, and increase in cation exchange capacity and stimulation of soil as flora and fauna.

Neem cake which is obtained from the seed kernels after extraction of the oil is needed for agricultural uses and soap production. Neem cake applications in soil have shown a stimulating effect on the blue-green algal growth, mainly by depressing predator's activity in the soil. Algae biomass was higher in treated soil than untreated situations. Neem cake is the residue obtained after the extraction of oil from neem seed. It contains more nitrogen (2-5\%), phosphorus (0.5-1.0\%), potassium (1 $-2 \%)$ calcium $(0.5-3 \%)$, magnesium $(0.3-1 \%)$ sulphur $(0.2 \%$ to 3.0 $\%)$, zinc (15 ppm to $60 \mathrm{ppm})$, copper (4 ppm to $20 \mathrm{ppm})$, manganese (20 ppm to $60 \mathrm{ppm}$ ) than farm yard manure or sewage sludge (Radwanksi and Wickens., 1981).

Vermi-compost is organic manure which is produced as the vermicast by earth worm feeding on biological waste material and plant residues. This compost is an odorless, clean and organic material containing adequate quantities of $\mathrm{N}, \mathrm{P}, \mathrm{K}$ and different micronutrients essential for plant growth. Vermi-compost is eco-friendly, non-toxic and consumes low energy input for composting and is a recycled biological product. Humic acids isolated from vermi-compost enhance the root elongation and formation of lateral roots in maize. Vermi-compost enhance the nutrient uptake by the plants by increasing the permeability of root cell membrane, stimulating root growth and increasing proliferation of root hairs (Pramanik et al., 2007).

The nutrients content in vermi-compost vary depending on the waste materials that are being used for compost preparation. If it is the waste materials are heterogeneous one, there will be wide range of nutrients available in the compost. The common available nutrients in vermi-compost are as follows: Organic carbon 9.5-17.98\%, Nitrogen 0.5-1.50\%, Phosphorous $0.1-0.30 \%$, Potassium $0.15-$ $0.56 \%$, Sodium- $0.06-0.30 \%$, Calcium and Magnesium 22.67- $47.60 \mathrm{meq} / 100 \mathrm{~g}$, Copper 2-9.50 $\mathrm{mg} \mathrm{kg}^{-1}$, Iron - 2-9.30 $\mathrm{mg} \mathrm{kg}^{-1}$, Zinc $5.70-1.50 \mathrm{mg} \mathrm{kg}^{-1}$, Sulphur $128-548 \mathrm{mg} \mathrm{kg}^{-1}$. It improves physic-chemical properties of the soil and enhances the microbial, crop growth and yield (Vasanthi and Kumaraswamy, 1999).

Azotobacter belongs to family Azotobacteriaceae, which are aerobic, free living, and heterotrophic in nature. Azotobacter is present in neutral or alkaline soils. A.chroococcum is the most commonly occurring species in aerable soils. $A$. vinelandii, $A$. beijerinckii, A.insignis and A.macrocytogenes are other reported species. The bacterium produces anti-fungal antibiotics which inhibits the growth of several pathogenic fungi in the root region thereby preventing seedling mortality to a certain 
extent. The population of Azotobacter is generally low in the rhizosphere of plants and in uncultivated soils.

Many heterotrophic bacteria and fungi efficiently solubilize insoluble phosphate in the soil as well as the inert phosphorus sources, its bacterial species to solubilise insoluble inorganic phosphate compounds, such as tri-calcium phosphate, dicalciumphosphate, hydroxyl-apatite and rockphosphate. Among the bacterial genera with this capacity are pseudomonas, Bacillus, Rhizobium, Burkholderia, Achromobacter, Agrobacterium, Microccocus, Aereobacter, Flavobacterium and Erwinia. There are present in considerable population in soil and in plant rhizospheres. These include both aerobic and anaerobic strains, with a prevalence of aerobic strains in submerged soils. A considerably higher concentration of phosphate solubilizing bacteria is commonly found in the rhizosphere in comparison with non-rhizosphere of soil. The soil bacteria are belonging to the genera. Pseudomonas and Bacillus and Fungi are more common.

The term Mycorrhiza denotes "fungus roots". It is refer to a symbiotic association between host plants and certain group of fungi at the root system, in which the fungal partner is benefited by obtaining its carbon requirements from the photosynthesis of the host and the host in turn is benefited by obtaining the much needed nutrients especially phosphorus, calcium, copper, zinc etc. which are accessible to it, with the help of the fine absorbing hyphae of the fungus.

These fungi are associated with majority of agricultural crops, except with those crops/plants belonging to families of Chenopodiaceae, Caryophyllaceae, Amaranthaceae, Polygonaceae, Brassicaceae, Commelinaceae, Juncaceae and Cyperaceae.

\section{Materials and Methods}

The experiment entitled "Influence of organic manures and bio-fertilizers on growth and development of Indian Basil (Ocimum sanctum 1.) cvs Cim-Ayu and Cim-Angana". Was conducted during the year 2017-18 under agro-climatic conditions of Prayagraj at the Research Farm, Department of Horticulture, SHUATS, Prayagraj, U.P. Plants with $8-10 \mathrm{~cm}$ height, 6-8 leaves and 4 branches were transplanted at spacing on using sandy clay soil.

The physical analysis of the used soil revealed that it was sandy clay loam soil which contained $21 \%, 25.75 \%$ and $53.25 \%$ clay, silt and sand, respectively. The soil chemical analysis cleared that, it contained the available $\mathrm{N}, \mathrm{P}$ and $\mathrm{K}$ values at $113,16.10$ and 215 $\mathrm{Kg} / \mathrm{ha}$ respectively. The electric conductivity (EC) was $7.85\left(\mathrm{dsm}^{-1}\right)$ with $\mathrm{pH}$ of 7.6

The experiment was laid out in factorial randomized block design (F.RBD) with 12 treatment and three replications. The total number of plots for Indian basil was 36 . The size of a unit plot was $1.80 \mathrm{~m} \times 1.20 \mathrm{~m}$.

\section{Varieties}

$\mathrm{V}_{1}:$ Cim - Ayu

$\mathrm{V}_{2}$ : Cim- Angana

Five plants from each plot were randomly selected and were labeled. These plants were used for recording all observations with respect to growth parameters.

The observation on following growth parameter were recorded and analyzed viz. Plant height $(\mathrm{m})$, Diameter of main stem $(\mathrm{cm})$, Number of Branches per plant, Number of leaves per plant and Plant spread per plant (m). 
The treatments were compared with the help of critical difference, following the techniques described by Panse and Sukhatme (1985) and results were evaluated at $5 \%$ level of significance.

\section{Results and Discussion}

The data presented in table 2 clearly showed that the organic manure and bio-fertilizer played significant role in affecting plant height. The maximum plant height was recorded $1.17 \mathrm{~m}$ with $\mathrm{T}_{11}$ in Cim - Ayu and 1.73 in Cim- Angana followed by $1.16 \mathrm{~m}$ with $\mathrm{T}_{10}$ in Cim - Ayu and $1.71 \mathrm{~m}$ in Cim- Angana. The minimum of plant height was recorded $1.07 \mathrm{~m}$ with $\mathrm{T}_{5}$ in Cim - Ayu and $1.24 \mathrm{~m}$ in Cim- Angana. The results are in close conformity with the finding of Naggar, et al., 2015.

The data presented in table 2 clearly showed that the diameter of main stem was significantly influenced by different organic manures and bio-fertilizers. The maximum diameter was observed in $9.18 \mathrm{~cm}$ with $\mathrm{T}_{9}$ in Cim - Ayu and $9.68 \mathrm{~cm}$ in Cim - Angana followed by treatment $\mathrm{T}_{10} 9.49 \mathrm{~cm}$ in Cim -
Ayu and $9.31 \mathrm{~cm}$ in Cim- Angana while, the lowest diameter of main stem was recorded $7.06 \mathrm{~cm}$ with $\mathrm{T}_{5}$ in Cim-Ayu and $6.91 \mathrm{~cm}$ in Cim-Angana.

The data presented in table 2 clearly showed that at 210 DAS, the maximum number of branches/plant was recorded 17.63 with $\mathrm{T}_{11}$ in Cim-Ayu and 17.19 Cim-Angana followed by 17.33 with $\mathrm{T}_{10}$ in Cim-Ayu and $17.03 \mathrm{Cim}-$ Angana while the lowest number of branches/plant was recorded 11.34 with $\mathrm{T}_{5}$ in Cim-Ayu and 11.11 in Cim- Angana. Similar results were observed by Naggar et al., 2015.

The data presented in table 2 clearly showed that the organic manure and bio-fertilizer played significant role in directly affecting number of leaves. The maximum number of leaves per plant was recorded significantly 1608.90 with $\mathrm{T}_{10}$ in Cim - Ayu and 1547.90 in Cim- Angana followed by 1524.80 with $\mathrm{T}_{11}$ in Cim - Ayu and 1503.00 in Cim- Angana. The minimum number of leaves was recorded 1247.30 with $T_{5}$ in Cim - Ayu and 1229.20 in Cim- Angana. The results were in close conformity with the finding of Rahman et al., (2014).

Table.1 Treatment details

\begin{tabular}{|c|c|l|}
\hline S. No & $\begin{array}{c}\text { Treatment } \\
\mathbf{S}\end{array}$ & \multicolumn{1}{|c|}{ Treatment combinations } \\
\hline $\mathbf{1 .}$ & $\mathrm{T}_{0}$ & 00:00 (Control) \\
\hline $\mathbf{2 .}$ & $\mathrm{T}_{1}$ & FYM @ 20 t/ha. \\
\hline $\mathbf{3 .}$ & $\mathrm{T}_{2}$ & P.S.B @ 20 t/ha. \\
\hline $\mathbf{4 .}$ & $\mathrm{T}_{3}$ & Vermicompost @ 6.0 t/ha. \\
\hline $\mathbf{5 .}$ & $\mathrm{T}_{4}$ & Neem Cake @ 3.0 t/ha. \\
\hline $\mathbf{6 .}$ & $\mathrm{T}_{5}$ & Azotobacter @ 6.0 kg/ha + Mycorrhiza @ $6.0 \mathrm{~kg} / \mathrm{ha}$ \\
\hline $\mathbf{7 .}$ & $\mathrm{T}_{6}$ & FYM 10 t/ha + Vermicompost @ 3.0 t/ha. \\
\hline $\mathbf{8 .}$ & $\mathrm{T}_{7}$ & Vermicompost @ 3.0 t/ha + P.S.B @ 10 t/ha. \\
\hline $\mathbf{9 .}$ & $\mathrm{T}_{8}$ & FYM 10 t/ha + Neem Cake @ 1.5 t/ha \\
\hline $\mathbf{1 0 .}$ & $\mathrm{T}_{9}$ & P.S.B @ 10 t/ha + Neem Cake @ 1.5 t/ha \\
\hline $\mathbf{1 1}$ & $\mathrm{T}_{10}$ & FYM 10 t/ha + P.S.B 10 t/ha.+ Neem Cake @ $1.5 \mathrm{t} / \mathrm{ha}+$ Azotobacter @ $6.0 \mathrm{~kg} / \mathrm{ha}$ \\
\hline $\mathbf{1 2 .}$ & $\mathrm{T}_{11}$ & FYM 10 t/ha + P.S.B 10 t/ha. + Neem Cake @ 1.5 t/ha + Mycorrhiza @ 6.0 kg/ha. \\
\hline
\end{tabular}


Table.2 Influence of organic manures and bio-fertilizers on growth and dry herbage yield of Indian Basil (Ocimum sanctum 1.) cvs Cim-Ayu and Cim-Angana

\begin{tabular}{|c|c|c|c|c|c|c|c|c|c|c|c|c|c|c|c|}
\hline \multirow[t]{2}{*}{ Treatments } & \multicolumn{3}{|c|}{ Height of plant (m) } & \multicolumn{3}{|c|}{$\begin{array}{c}\text { Diameter of main } \\
\text { stem }(\mathbf{c m})\end{array}$} & \multicolumn{3}{|c|}{ No. of Branches/Plant } & \multicolumn{3}{|c|}{ No. of leaves /Plant } & \multicolumn{3}{|c|}{$\begin{array}{c}\text { Dry herbage } \\
\text { yield/plant (kg) }\end{array}$} \\
\hline & $V_{1}$ & $\mathbf{V}_{2}$ & Mean & $V_{1}$ & $\mathbf{V}_{2}$ & Mean & $V_{1}$ & $\mathbf{V}_{2}$ & Mean & $V_{1}$ & $\mathbf{V}_{2}$ & Mean & $V_{1}$ & $V_{2}$ & Mean \\
\hline T0 & 1.10 & 1.47 & 1.28 & 7.11 & 7.06 & 7.07 & 12.75 & 12.33 & 12.54 & 1377.50 & 1349.60 & 1363.55 & 2.21 & 2.11 & 2.16 \\
\hline T1 & 1.12 & 1.52 & 1.32 & 7.11 & 7.06 & 7.08 & 14.40 & 14.33 & 14.37 & 1446.20 & 1380.90 & 1413.55 & 2.38 & 2.31 & 2.35 \\
\hline $\mathbf{T} 2$ & 1.13 & 1.65 & 1.40 & 8.56 & 8.04 & 8.30 & 16.56 & 16.33 & 16.45 & 1537.40 & 1486.60 & 1512.00 & 3.21 & 2.89 & 3.05 \\
\hline T3 & 1.14 & 1.63 & 1.38 & 7.13 & 7.39 & 7.26 & 13.66 & 13.52 & 13.59 & 1395.30 & 1374.50 & 1384.90 & 2.15 & 2.19 & 2.17 \\
\hline $\mathbf{T 4}$ & 1.15 & 1.61 & 1.37 & 7.86 & 7.23 & 7.54 & 15.33 & 15.13 & 15.23 & 1454.30 & 1432.30 & 1443.30 & 2.58 & 2.43 & 2.51 \\
\hline T5 & 1.07 & 1.42 & 1.24 & 7.06 & 6.91 & 6.98 & 11.34 & 11.11 & 11.23 & 1247.30 & 1229.20 & 1238.25 & 1.98 & 2.03 & 2.01 \\
\hline T6 & 1.14 & 1.57 & 1.32 & 7.29 & 7.91 & 7.60 & 14.33 & 14.05 & 14.19 & 1464.10 & 1347.40 & 1405.75 & 2.37 & 2.09 & 2.23 \\
\hline T7 & 1.13 & 1.58 & 1.35 & 8.23 & 7.51 & 7.87 & 15.83 & 15.36 & 15.60 & 1475.50 & 1430.70 & 1453.10 & 2.58 & 2.52 & 2.55 \\
\hline T8 & 1.12 & 1.66 & 1.39 & 8.15 & 7.67 & 7.91 & 14.72 & 14.66 & 14.69 & 1469.90 & 1389.70 & 1429.80 & 2.45 & 2.32 & 2.39 \\
\hline T9 & 1.11 & 1.69 & 1.40 & 9.68 & 9.47 & 9.43 & 16.33 & 15.74 & 16.04 & 1517.20 & 1475.10 & 1496.15 & 2.93 & 2.75 & 2.84 \\
\hline T10 & 1.16 & 1.71 & 1.43 & 9.49 & 9.31 & 9.40 & 17.33 & 17.03 & 17.26 & 1608.90 & 1547.90 & 1578.40 & 3.24 & 2.96 & 3.10 \\
\hline T11 & 1.17 & 1.73 & 1.45 & 9.25 & 8.85 & 9.05 & 17.63 & 17.19 & 16.63 & 1524.80 & 1503.00 & 1513.90 & 3.19 & 2.88 & 3.06 \\
\hline \multirow[t]{2}{*}{ Average } & 1.13 & 1.60 & 1.35 & 8.03 & 7.88 & 7.96 & 15.02 & 14.62 & 14.82 & 1459.87 & 1412.24 & 1436.05 & 2.61 & 2.46 & 2.53 \\
\hline & V & $\mathrm{T}$ & $\mathrm{V} \times \mathrm{t}$ & V & $\mathrm{T}$ & $\mathrm{V} \times \mathrm{t}$ & V & $\mathrm{T}$ & $\mathrm{V} \times \mathrm{t}$ & V & $\mathrm{T}$ & $V \times t$ & V & $\mathrm{T}$ & $V \times t$ \\
\hline C.D.(0.05) & 0.038 & 0.015 & 0.249 & 0.094 & 0.231 & 0.327 & 0.163 & 0.399 & 0.564 & 16.030 & 39.265 & 55.530 & 0.030 & 0.072 & 0.102 \\
\hline SEm \pm & \multicolumn{3}{|c|}{6.69} & \multicolumn{3}{|c|}{6.95} & \multicolumn{3}{|c|}{6.59} & \multicolumn{3}{|c|}{6.70} & \multicolumn{3}{|c|}{7.01} \\
\hline
\end{tabular}


The data presented in table 2 clearly showed that the maximum dry herbage yield/plant $(\mathrm{kg})$ of Tulsi was significantly influenced by different manures and bio-fertilizer. The maximum dry herbage yield/plant 3.24 $\mathrm{kg} / \mathrm{plant}$ was obtained with $\mathrm{T}_{10}$ in Cim - Ayu and 2.96 in Cim- Angana followed by 3.21 $\mathrm{kg} /$ plant with $\mathrm{T}_{2}$ in Cim - Ayu and 2.89 in Cim - Angana. The Minimum dry herbage yield was recorded $1.98 \mathrm{~kg} / \mathrm{plant}$ with $\mathrm{T}_{5}$ in Cim - Ayu and $2.03 \mathrm{~kg} / \mathrm{plant}$ in Cim Angana. Similar result was observed by Patel and Kushwaha (2013).

In the view of experimental results it is concluded that the treatment $\mathrm{T}_{11}$ and $\mathrm{T}_{10}$ were found the best among all treatment combinations for growth and dry herbage yield of Indian basil under organic manures and bio-fertilizers. This result might be due to followings reasons.

Organic manure (FYM + Vermicompost + Neem Cake) and Bio-fertilizers (Azotobacter + mycorrhiza + PSB), had articulated impact on growth characters of Indian basil crop. Based on present investigation, it was accounted that the plant height was increased notably with the utilization of Organic manure + bio-fertilizers, at various treatment combinations. The expansion in vegetative growth parameters may be because of the generation of more chlorophyll content with inoculation of nitrogen fixers. The other logical explanation behind increased vegetative growth might be the creation of plant growth regulators by microorganism in rhizosphere, which are absorbed by the roots.

Vemicompost is considered as a rich source of available plant nutrients, growth regulators, enzymes, antifungal and antibacterial compound (Arancon et al., 2004).

Azotobacter is one of the most intensively investigated free living nitrogen fixing bacteria and apart from having ability to fix atmospheric nitrogen it is also known to synthesize biologically active PGRs such as IAA, GA etc. (Yadav et al., 2013).

Besides, mentioned earlier, increased plant height might be due to Azotobacter and Mycorrhyza as it influences the nitrogen, which is the chief constituent of protein that is required for the formation of protoplasm that enhances the cell division as well as cell enlargement. The mechanism by which PSB augments plant growth is by dissolution of phosphate (Nowsheen et al., 2006) and through biosynthesis of auxins (Sattar and Gaur, 1987) and Indole Acetic Acid (Bareae et al., 1976).

It also provides protection against nonparasitic root pathogens and transforms the unavailable minerals as well as organic compounds into available forms into the soil, leading to increase in vegetative growth of the plants. This increase in plant height with the application of Organic manure (FYM + Vermicompost + Neem Cake) and Biofertilizers (Azotobacter + mycorrhiza + PSB), over the span of investigation get the support of Singh and Singh (2002), Nowsheen et al., (2006) and Tripathi et al., 2010. Similar results were also recorded for vegetative growth (plant height, number of branches, leaves numbers, Plant spread by Naggar et al., 2015.

\section{References}

Arancon, N.Q., Edwards, C.A., Bierman, P., Welch, C. and Metzger, J.D. (2004). Influences of vermicomposts on field strawberries: Effect on growth and yields. Bioresource Tech., 93(2): 145-153.

Bareae, J.M., Navarro, E. and Montoya, E. (1976). Production of plant growth regulators by rhizosphere phosphatesolubilizing bacteria. J. Applied Bacteriol., 40: 129-134. 
Blank, A.F., Carvalho, F.J.L.S., Santos N.A.L. and Alves, P.B. (2004). Effect of plant density and harvesting time on the yield and the quality of essential oil in Ocimum species. Hort. Brasileira.22: 113-116.

Mondello, L., Zappia, G., Cotroneo, A., Bonaccorsi, I., Chowdhury, J.U.., Yusuf, M., Dugo, G., (2002). Studies on the essential oil-bearing plants of Bangladesh. Part VIII. Composition of some Ocimum oils $O$. basilicum L. var. purpurascens; $O$. sanctum L. green; O.sanctum L. purple; $O$. americanum L., citral type; $O$. americanum L., camphor type. Flavour Fragr. J., 17: 335-340.

Naggar, A.H.M.E, Hassan, M.R.A., Shaban, E.H. and Mohamed, M.E.A., (2015). Effect of Organic and Bio-fertilizers on growth, oil yield and chemical composition of the essential oil of Ocimum basillicum L. Plants, Alex. J. Agric. Res., 60(1): 1-16.

Nowsheen, N., Singh, S.R., Aroosa, K., Masarat, J., and Shabeena, M. (2006). Yield and growth of strawberry cv. Senga Sengana as influenced by integrated organic nutrient management system. Environ. and Eco., 24 (3): 651-654.

Panse, V.G. and Sukhatme, P.V. (1985). Statistical method for Agriculture Workers. ICAR, New Delhi.

Patel, K. and Kushwaha N.K. (2013). Studies on influence of species, nitrogen and spacing on parameters of plant growth at various stages of basil. Int. J. Pharm. and Life Sci. 4(10): 3028-3034.

Pramanik, P., Ghosh, G. K., Ghosal, P. K. and Banik, P. (2007). Changes in organic-C,
$\mathrm{N}, \mathrm{P}$ and $\mathrm{K}$ and enzyme activities in vermicompost of biodegradable organic wastes under liming and microbial inoculants. J. Biores. Tech.98: 2485-2494.

Radwanksi, S.A. and Wickens, G.E. (1981). Vegetative fallows and potential value of the neem tree in thetropics. Econ. Botany. 35: 398-414

Rahman, K.M., Sattar, M.A. and Rahman, G.M.M. (2014). Effect of Fertilizer and Manures on Growth and Yield of Tulsi and Pudina Medicinal Plant, J. Environ. Sci. and Natural Res., 7(2): 13-16.

Sattar, M.A. and Gaur, A.C. (1987). Production of auxins and gibberellins by phosphate dissolving microorganisms. Zentral. Microbiol., 142: 393-395.

Singh, M. and Singh, R. (2002). Response of sweet basil (Ocimum basilicum) to organic and inorganic fertilizer in semiarid tropical condition. J. Medi. and Aromatic Plant Sci., 24 (4): 947-950.

Singh, S., Taneja, M., and Majumdar, K.D. (2007). Biological activity of Ocimum sanctum L. fixed oil-An overview. Ind $J$ of Exp Biology, 45: 403-412.

Tripathi, V.K., Kumar, N., Shukla, H.S. and Mishra, A.N. (2010). Influence of Azotobacter, Azospirillum and PSB on growth, yield and quality of strawberry cv. Chandler, paper presented in National Symposium on Conservation Hort., Deharadoon, pp 198-199.

Yadav., R.K. and Prasad, M. (2013). Usage of holy basil for various aspects, Bulletin of Envi, Pharma. and Life Sci., 1(10): 67-69.

\section{How to cite this article:}

Rajit Ram, V.M. Prasad, Vijay Bahadur, Joy Dowsan, Narendra Swaroop and Anil Kumar. 2019. Influence of Organic Manures and Bio-fertilizers on Growth and Yield of Indian Basil (Ocimum sanctum L.) cvs Cim-Ayu and Cim-Angana. Int.J.Curr.Microbiol.App.Sci. 8(10): 2385-2392. doi: https://doi.org/10.20546/ijcmas.2019.810.276 